\title{
CHEMICAL DEGRADATION OF PCDD/F IN CONTAMINATED SEDIMENT
}

\author{
CHEMICZNA DEGRADACJA PCCD/F \\ W ZANIECZYSZCZONYM SEDYMENCIE
}

\begin{abstract}
Due to the extreme toxicity of polychlorinated dibenzo- $p$-dioxins and dibenzofurans (PCDD/F), the remediation of PCDD/F aquifer source zones is greatly needed; however, it is very difficult due to their persistence and recalcitrance. The potential degradability of PCDD/F bound to a real matrix was studied in five systems: iron in a high oxidation state (ferrate), zero-valent iron nanoparticles (nZVI), palladium nanopowder (Pd), a combination of nZVI and Pd, and persulfate (PSF). The results were expressed by comparing the total toxicity of treated and untreated samples. This was done by weighting the concentrations of congeners (determined using a standardized GC/HRMS technique) by their defined toxicity equivalent factors (TEF). The results indicated that only PSF was able to significantly degrade PCDD/F. Toxicity in the system decreased by $65 \%$ after PSF treatment. Thus, we conclude that PSF may be a potential solution for in-situ remediation of soil and groundwater at PCDD/F contaminated sites.
\end{abstract}

Keywords: PCDD/F, ferrate, nZVI, Pd, persulfate, degradation

\section{Introduction}

Polychlorinated dibenzo-p-dioxins (PCDD) and polychlorinated dibenzofurans (PCDF) are without doubt the highest priority groups of pollutants. They belong to the first groups of pollutants (called the Dirty Dozen) to be inscribed under the Stockholm Convention on Persistent Organic Pollutants (POPs) in 2001. The aim of this convention is to protect human health and the environment from harmful and widely distributed chemicals by requiring its parties to eliminate or reduce the release of POPs into the environment [1].

Contrary to all other POPs, $\mathrm{PCDD} / \mathrm{F}$ were never intentionally produced as organochlorinated pesticides as they are exclusively impurities/by-products with a varying origin. $\mathrm{PCDD} / \mathrm{F}$ are highly toxic for human health and wildlife, remain intact in the environment for long periods of time, are widely distributed throughout the environment, and bioaccumulate in fatty tissues of humans and animals. Their toxic effect is mediated

\footnotetext{
${ }^{1}$ Faculty of Mechatronics, Informatics and Interdisciplinary Studies \& the Institute for Nanomaterials, Advanced Technologies and Innovation, Technical University of Liberec, Studentská 1402/2 Liberec, 46117, Czech Republic, phone +420 485353 848, fax +420 485353696

*Corresponding author: martina.homolkova@tul.cz
} 
through the interaction with an intracellular protein, the aryl hydrocarbon receptor (AHR) [2], which occurs in most vertebrate tissues and affects a number of other regulatory proteins. The toxicity of PCDD/F depends on the number and position of the chlorine atoms in their molecule. Congeners with chlorines in the 2, 3, 7, and 8 positions have the highest affinity to the AH receptor and are therefore significantly harmful. Seven dioxins and ten furans have chlorines in these relevant positions and are considered toxic by the WHO-TEQ scheme (World Health Organization Toxic Equivalent) [2]. The most toxic dioxin is reported to be 2,3,7,8-tetrachlorodibenzo-p-dioxin (TCDD), which is the strongest known human carcinogen according to the International Agency for Research on Cancer [3]. On the contrary, PCDD/F containing between one and three chlorine atoms are not considered to be toxicologically serious, whereas other organic molecules, for example coplanar PCB or polychlorinated naphthalenes, possess dioxin-like toxicity $[4,5]$.

The WHO-TEQ scheme was adopted internationally as the most appropriate way of estimating the potential health risks of mixtures of PCDD/F as there are 75 PCDD and 135 PCDF possible congeners. The total TEQ value expresses the total sample toxicity as if only TCDD congener would be present. Each of the seven dioxin and ten furan toxic congeners is given a toxicity ranking called the toxic equivalency factor (TEF) from 0 to 1 , where the reference congener is TCDD which by definition has a TEF $=1$. Their concentration is then weighted by their TEF, which gives a congener contribution to the sample TEQ. Alternatively to calculating the specific congener contributions after GC/HRMS determination, a screening method based on cell-line with sensitized AHR could be used [4].

The remediation of $\mathrm{PCDD} / \mathrm{F}$ contaminated soil is generally very difficult. Post-excavation soil cleaning methods mostly employ physical or chemical methods like thermal treatment $[6,7]$, surfactant washing $[8,9]$ or base-catalysed decomposition [10] of PCDD/F.

In this paper, we studied the potential degradation of $\mathrm{PCDD} / \mathrm{F}$ bound to a real soil matrix by applying five different oxidants and reductants with a potential for in-situ remediation. Two extreme oxidation states of iron were tested: $\mathrm{Fe}^{0}$ nanoparticles (zero-valent iron nanoparticles, nZVI) and $\mathrm{Fe}^{+6}$ (ferrate, $\mathrm{Fe}(\mathrm{VI})$ ). Ferrate is a very strong oxidant whose superior performance for environmental remediation has been demonstrated in various recent researches [11-13]. On the other hand, ZVI in the form of nanoparticles is a strong reductant with a large specific surface and has been utilized for groundwater remediation and wastewater treatment $[14,15]$. The second metal having a potential dechlorination capability was the catalytic, noble metal palladium in the form of a nanopowder. A combination of Pd and nZVI was also studied as it has been reported that such a combination improves the degradation rates of chlorinated compounds [16, 17] including PCDD/F $[18,19]$. Finally, heat-activated PSF was tested as sulfate and hydroxyl radical generator. $\mathrm{SO}_{4}{ }^{-}$and $\mathrm{OH}^{*}$ are one of the strongest known oxidants used for in situ chemical oxidation in the remediation of soil and groundwater [20].

\section{Materials and methods}

\section{Chemicals}

$\mathrm{PCDD} / \mathrm{F}$ was used in the form of an industrial sandy soil certified reference material (BCR 529) [21] obtained from Sigma Aldrich. Information on the presence of the certified concentrations of $\mathrm{PCDD} / \mathrm{F}$ is given in Table 1 . The certified values were not available for 
all of the congeners presented in the material; however, the concentrations of the other congeners were determined through analysis and were in good agreement with the data obtained by Antunes et al [22]. The toxicity equivalent factors (TEF) [23] used for dioxins are also given in Table 1.

Composition of the certified reference material [21] and the TEF values [23]

Table 1

\begin{tabular}{|c|c|c|c|}
\hline PCDD/F (\#) & $\begin{array}{c}\text { Certified value } \\
{[\mu \mathrm{g} / \mathrm{kg}]}\end{array}$ & $\begin{array}{c}\text { Uncertainty } \\
{[\mu \mathrm{g} / \mathrm{kg}]}\end{array}$ & TEF \\
\hline $2,3,7,8-\mathrm{TCDD}(\mathrm{D} 1)$ & 4.5 & 0.6 & 1 \\
\hline $1,2,3,7,8-\mathrm{PeCDD}$ (D2) & 0.44 & 0.05 & 0.5 \\
\hline 1,2,3,4,7,8-HxCDD (D3) & 1.22 & 0.21 & 0.1 \\
\hline $1,2,3,6,7,8-\mathrm{HxCDD}$ (D4) & 5.4 & 0.9 & 0.1 \\
\hline 1,2,3,7,8,9-HxCDD (D5) & 3.0 & 0.4 & 0.1 \\
\hline $1,2,3,4,6,7,8-\mathrm{HpCDD}$ (D6) & - & - & 0.01 \\
\hline OCDD (D7) & - & - & 0.001 \\
\hline $2,3,7,8-\mathrm{TCDF}(\mathrm{F} 1)$ & 0.078 & 0.013 & 0.1 \\
\hline $1,2,3,7,8-\mathrm{PeCDF}(\mathrm{F} 2)$ & 0.145 & 0.028 & 0.05 \\
\hline 2,3,4,7,8-PeCDF (F3) & 0.36 & 0.07 & 0.5 \\
\hline $1,2,3,4,7,8-\mathrm{HxCDF}(\mathrm{F} 4)$ & 3.4 & 0.5 & 0.1 \\
\hline $1,2,3,6,7,8-\mathrm{HxCDF}(\mathrm{F} 5)$ & 1.09 & 0.15 & 0.1 \\
\hline $2,3,4,6,7,8-\mathrm{HxCDF}(\mathrm{F} 6)$ & 0.37 & 0.05 & 0.1 \\
\hline $1,2,3,7,8,9-\mathrm{HxCDF}(\mathrm{F} 7)$ & 0.022 & 0.010 & 0.1 \\
\hline $1,2,3,4,6,7,8-\mathrm{HpCDF}(\mathrm{F} 8)$ & - & - & 0.01 \\
\hline $1,2,3,4,7,8,9-\mathrm{HpCDF}(\mathrm{F9})$ & - & - & 0.01 \\
\hline OCDF (F10) & - & - & 0.001 \\
\hline
\end{tabular}

Potassium ferrate was provided by the company LAC. The content of $\mathrm{Fe}$ was determined by elemental analysis as being $25.5 \% \mathrm{Fe}$. Room temperature ${ }^{57} \mathrm{Fe}$ Mossbauer spectroscopy determined the iron oxidation states as follows: $5 \% \mathrm{Fe}(\mathrm{V}), 7 \% \mathrm{Fe}(\mathrm{VI})$ and $88 \%$ of $\mathrm{Fe}(\mathrm{III})$. This implies that the ferrate powder contained $5.5 \% \quad \mathrm{~K}_{3} \mathrm{FeO}_{4}$ and $6.5 \% \mathrm{~K}_{2} \mathrm{FeO}_{4}$.

Standard NANOFER 25P nZVI (NANO IRON, s.r.o., Olomouc, Czech Republic) was used in the form of a dry powder preserved in an inert nitrogen atmosphere. The particles were without surface modification and had an average size of $50 \mathrm{~nm}$, average surface area of $20-25 \mathrm{~m}^{2} / \mathrm{g}$ and a narrow size distribution of 20-100 $\mathrm{nm}$. The content of iron was high, ranging between 80 and 90 wt. \%. An aqueous suspension of $\mathrm{Fe}^{0}$ was prepared from the powder at a ratio of 1:4 nZVI:water, which yielded a suspension with an nZVI content of $200 \mathrm{~g} \mathrm{Fe}^{0} / \mathrm{dm}^{3}$.

Palladium nanopowder $(<25 \mathrm{~nm})$ with purity $99.9 \%$ was obtained from Aldrich. Sodium persulfate (PSF) of p.a. quality was obtained from Penta.

\section{Methods}

A total of $1.0 \mathrm{~g}$ of the certified BCR-329 material was placed into each reactor containing $522.5 \mathrm{~cm}^{3}$ of demineralized water and stirred vigorously for 30 minutes. After that, the appropriate reactant (Fe(VI), nZVI, Pd, Pd+nZVI and PSF) was added. The reaction times differed in accordance to the reactant used. The dosed amounts of the individual chemicals together with durations of reactions are summarized in Table 2 . The reaction of $\mathrm{PCDD} / \mathrm{F}$ with $\mathrm{Fe}(\mathrm{VI})$ and $\mathrm{nZVI}$ was performed in triplicate and the reaction with $\mathrm{Pd}, \mathrm{Pd}+\mathrm{nZVI}$ and PSF in duplicate. The base samples consisting of water and PCDD/F 
only were repeated nine times in total with reaction times ranging from 3 to 60 days, thus covering all of the different reaction times used in this study. PSF was activated by heat, namely at $50^{\circ} \mathrm{C}$, during the whole reaction time.

Dosed amounts and the reaction times

Table 2

\begin{tabular}{|c|c|c|c|c|c|}
\hline & Reaction time $^{*}$ & Fe(VI) & nZVI & Pd & PSF \\
\hline Base & 3-60 days & - & - & - & - \\
\hline Fe(VI) & 3 days & $1.0 \mathrm{~g}$ & - & - & - \\
\hline nZVI & 60 days & - & $5.0 \mathrm{~g}$ & - & - \\
\hline Pd & 22 days & - & - & $0.1 \mathrm{~g}$ & - \\
\hline Pd+nZVI & 22 days & - & $5.0 \mathrm{~g}$ & $0.1 \mathrm{~g}$ & - \\
\hline PSF & 7 days & - & - & - & $10.0 \mathrm{~g}$ \\
\hline
\end{tabular}

* reaction times were chosen on the previous experience with reagents reactivity - no remaining reducing/oxidizing effect is supposed to persist in reactors at the end of the reaction time

\section{Analytical methods}

The samples were processed in a commercial laboratory (ALS) by the standard extraction and cleaning procedure for $\mathrm{PCDD} / \mathrm{F}$, including the addition of the appropriate ${ }^{13} \mathrm{C}_{12}$ labelled internal standards according to EN 1948-2 [24]. The separation, identification and determination of PCDD/F in the extracts containing the standards for determining the recoveries were performed using GC/HRMS according to EN 1948-3 [25]. The seventeen congeners listed in Table 1 were determined.

\section{Results and discussion}

For clarity and simplification, all of the results were expressed as toxicity equivalency values (TEQ), which is a summary parameter evaluating the congener concentration weighted by its TEF.

The composition of the base samples was determined and the results were expressed as TEQ of each PCDD/F congener in each base sample as shown in Figure 1. Furthermore, the TEQ contribution of each average PCDD/F congener to the overall toxicity of the average base sample is shown in Figure 2. The total TEQ of the average base was determined as $11.138 \mathrm{ng} / \mathrm{g}$.

It is apparent from Figure 2 that almost two thirds (specifically $6.8 \mathrm{ng} / \mathrm{g}$, which corresponds to $61.1 \%$ ) of the overall TEQ resulted from the D1 congener. The other relatively high contributions (but significantly lower in comparison to D1) were $7.4 \%$ and $6.0 \%$ for D4 and D6, respectively. The lowest TEQ was exhibited by F1, F2 and F9.

$\mathrm{PCDD} / \mathrm{F}$ samples were treated by iron in its two extreme oxidation states, $\mathrm{Fe}^{0}$ (nZVI) and $\mathrm{Fe}^{+6}(\mathrm{Fe}(\mathrm{VI})$, ferrate), by palladium nanopowder $(\mathrm{Pd})$, by a combination of Pd with nZVI and by PSF. The overall results of this study are summarized in Figure 3 where the columns represent summary TEQ values of all of the congeners. With the exception of the PSF treated samples, no significant degradation of the sum of PCDD/F was observed for any of the reactants. A distinct decrease in the overall PCDD/F toxicity and thus overall PCDD/F content was caused solely by PSF. This decrease was from 11.1 to $3.9 \mathrm{ng} / \mathrm{g}$, which corresponded to $65 \%$. 

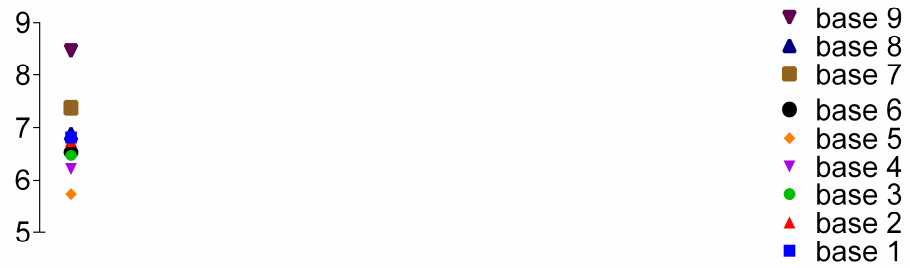

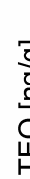
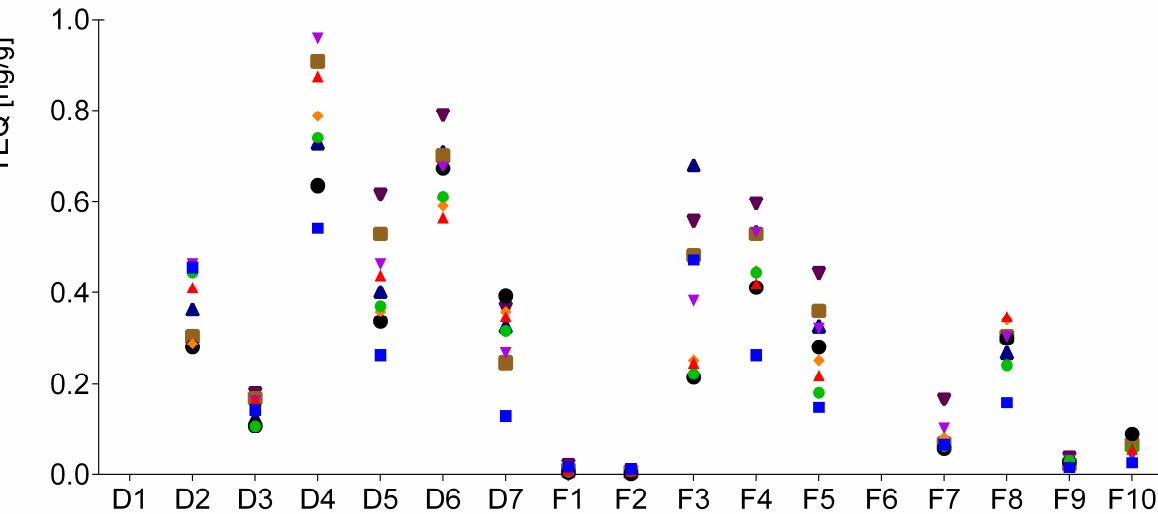

Fig. 1. TEQ of individual congeners in base samples

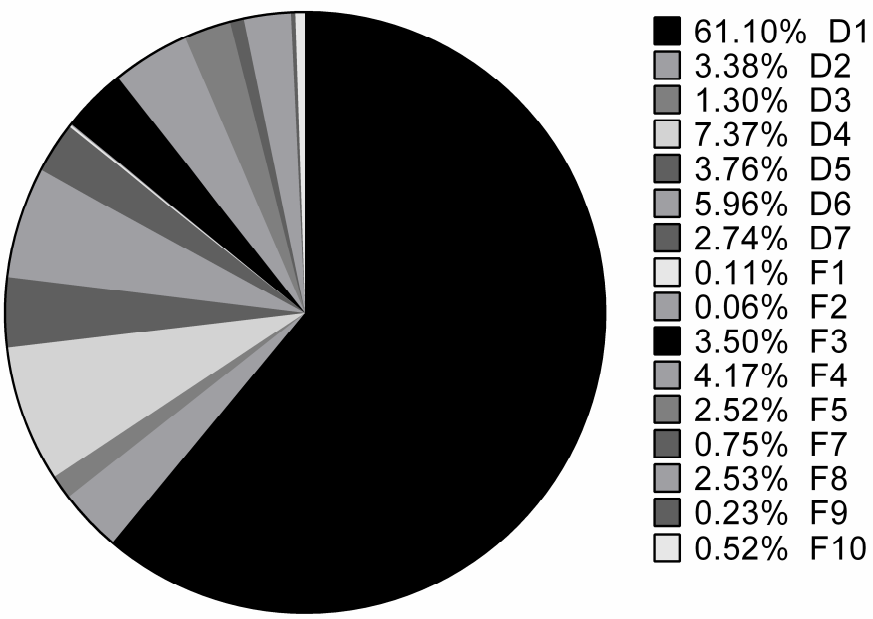

Total TEQ $=11.138[\mathrm{ng} / \mathrm{g}]$

Fig. 2. Contribution of individual congeners to the overall toxicity of the base

Contrary to the PSF treated sample and to our presumption, the TEQ in ferrate treated samples increased. This could be explained by the ferrate oxidation of the real matrix containing PCDD/F, which could help/contribute to the release of PCDD/F bound to the matrix and thus a higher extraction yield could have been caused. However, the increase in 
TEQ may also have been caused solely by experiment error, as the difference between the base and ferrate treated samples is within the range of standard deviation. The relatively high standard deviation ranges in the case of the ferrate and nZVI treated samples could be explained by difficult dosing of these two particular chemicals due to their inhomogeneity. In the case of ferrate, the inhomogeneity lies in the solid sample itself which was dosed; whereas nZVI was dosed in the form of an aqueous suspension, which is known to solve the problem of nZVI sedimentation and/or aggregation [26]. Neither nZVI (despite the highly reactive pyrophoric form used), nor $\mathrm{Pd}$, nor even their combination, caused any significant degradation. As mentioned above, according to Kim et al [18], the combination of nZVI and Pd rapidly dechlorinates PCDD. However, in their study bimetallic palladized nanosized ZVI $(\mathrm{Pd} / \mathrm{nFe})$ was used. In contrast, only a simple mixture of $\mathrm{nZVI}$ and nanosized Pd was used in our experiment. This fact may explain our negative result, as such a contact between the two surfaces was not achieved in our study.

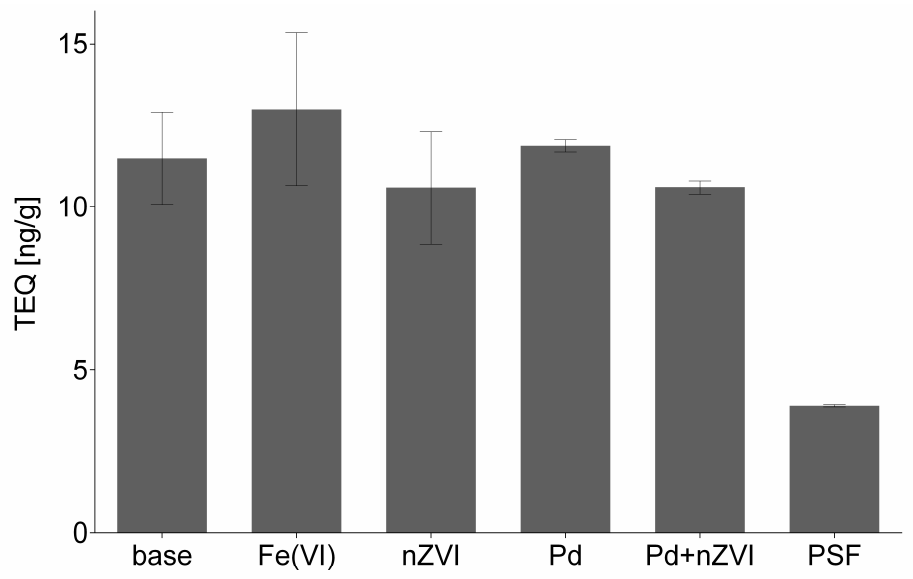

Fig. 3. Summary of the whole study expressed in TEQ values (mean \pm standard deviation)

The behavior of the individual congeners in the PSF treated samples and their contribution to the overall decline in TEQ are shown in Figure 4. The rate of decline differed for each PCDD/F congener; however, it is apparent that there was a decrease in each of them. No increase in the concentration of any of the congeners was observed. The most significant contribution to the overall decrease was exhibited by congeners D1, D2 and D4. When taking into account the relative values, the highest relative decline was observed for D2, F1 and F2, which decreased by $97.1,91.4$ and $85.3 \%$, respectively; whereas the lowest observed decline was 28.5, 47.0 and $47.5 \%$ for F8, D6 and D7, respectively. One can conclude that high reactivity of PSF towards PCDD/F congeners can be due to the high reaction rate between both sulfate and hydroxyl radicals and the electron rich bonds in aromatic rings [27, 28].

As there was a different rate of decline of each PCDD/F congener after PSF treatment, their relative contribution to the overall toxicity of the sample changed (Fig. 5) compared to the base sample (Fig. 2). The highest contribution, more than one half, was still conclusively caused by D1, but the others did not lag so far behind this time. The highest 
contributions to the total TEQ of PSF treated samples were 53.8, 9.5 and $9.0 \%$ for D1, D4 and D6, respectively.

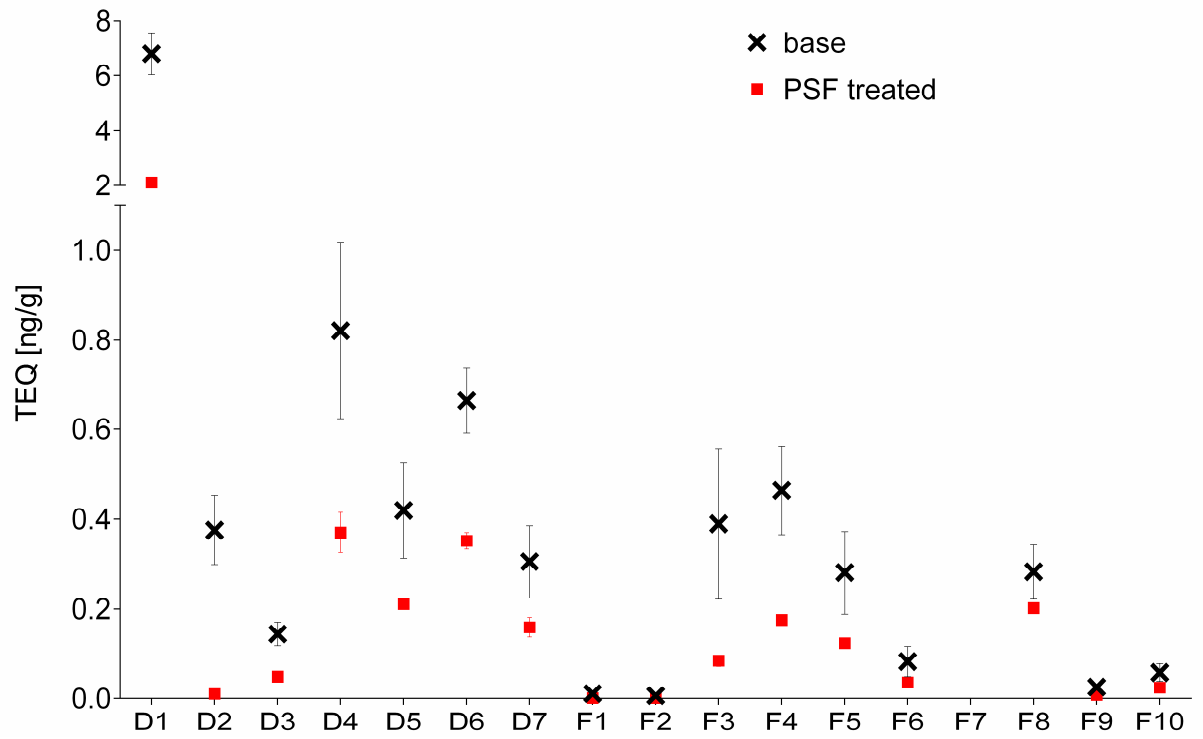

Fig. 4. Decline of individual congeners in the PSF treated samples (mean \pm standard deviation)

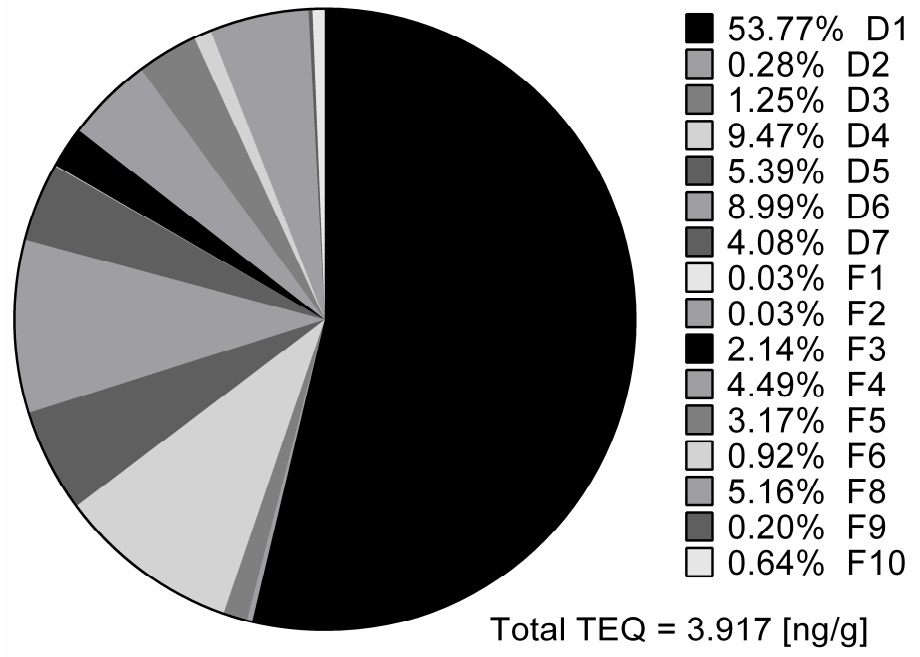

Fig. 5. Contribution of individual congeners to the overall toxicity of PSF treated samples

Only a few studies are comparable with our system. Kim et al [29] described approximately $15 \%$ TCDD degradation in a heat-activated persulfate system. In contrast to 
the real soil matrix that we report here, Kim et al [29] dosed TCDD as being solventdissolved and started the reaction after complete acetone evaporation.

The behavior of individual congeners and their contribution to the overall PCDD/F TEQ increase in $\mathrm{Fe}(\mathrm{VI})$ treated samples is shown in Figure 6. It can be assumed that the overall behavior was caused mostly by D1 and partly by D4. Other congeners with increasing concentrations were D3, D5, D7, F2, F6 and F10. On the other hand, there are also congeners with decreasing concentrations. The highest relative decrease was observed in the case of F9 and F5 with 23.7 and $20.0 \%$, respectively.

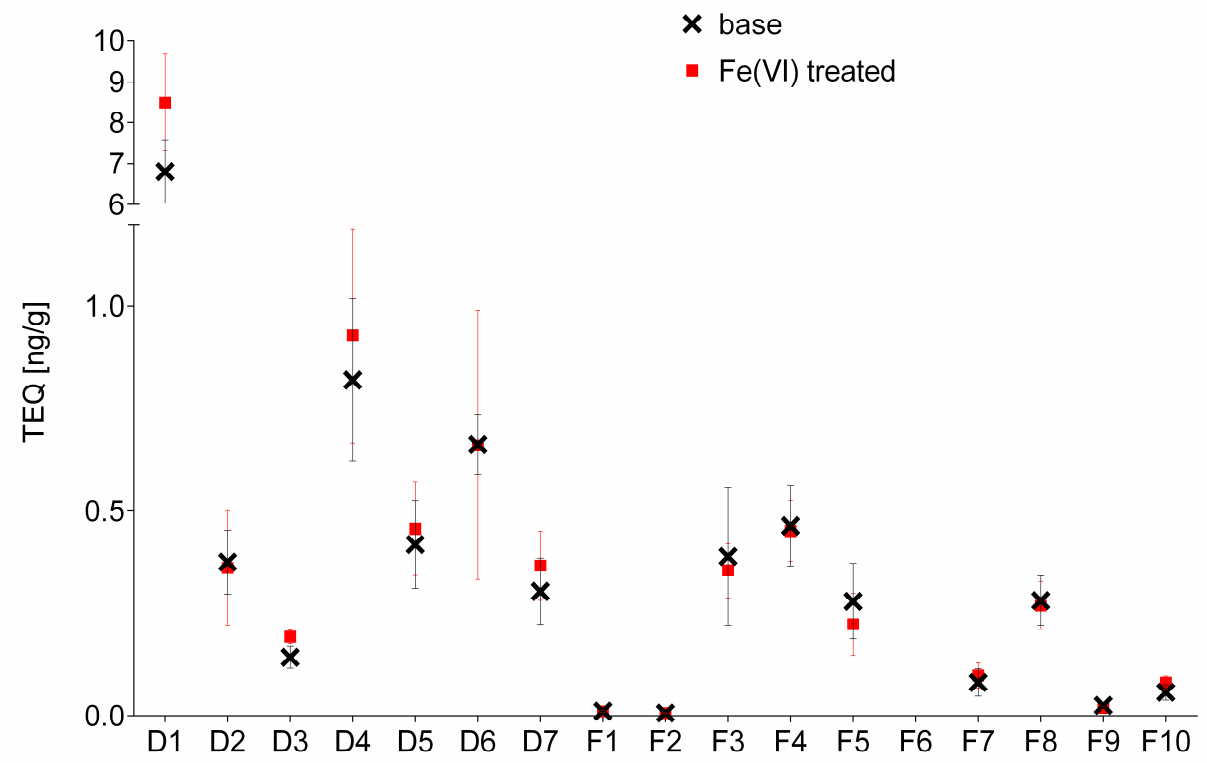

Fig. 6. Behavior of individual congeners in the Fe(VI) treated samples (mean \pm standard deviation)

\section{Conclusions}

In this paper the potential degradation of PCDD/F bound to a real matrix was studied by five different oxidants and reductants commonly used for in-situ remediation, ie $\mathrm{Fe}(\mathrm{VI})$, nZVI, Pd, Pd+nZVI and PSF. We conclude that only the treatment by sulfate and hydroxyl radicals formed in the heat-activated PSF system exhibited a significant decrease in the $\mathrm{PCDD} / \mathrm{F}$ concentrations. This decrease was $65 \%$ when comparing the total toxicity of the base and the treated samples. Thus, PSF activated at $50^{\circ} \mathrm{C}$ may be used for the remediation of aquifers contaminated by these priority pollutants. Future research should be devoted to studying wider range of activation temperatures, whereby the lower ones are of much technological interest. Other PSF activation procedures (electroactivation, alkaline activation or hydrogen peroxide activation as examples) have also a potential to create strongly mineralising conditions applicable for PCDD/F degradation. 


\section{Acknowledgements}

The work was supported by the project OPR\&DI of the Centre for Nanomaterials, Advanced Technologies and Innovation (CZ.1.05/2.1.00/01.0005), the National Programme for Sustainability I (LO1201) and by the Ministry of Education, Youth and Sports of the Czech Republic through the SGS project 21066/115.

\section{References}

[1] Stockholm Convention on Persistent Organic Pollutants. http://chm.pops.int.

[2] Van den Berg M, Birnbaum LS, Denison M, De Vito M, Farland W, Feeley M, et al. The 2005 World Health Organization reevaluation of human and Mammalian toxic equivalency factors for dioxins and dioxin-like compounds. Toxicol Sci. 2006;93(2):223-241. DOI: 10.1093/toxsci/kfl055.

[3] International Agency for Research on Cancer. http://monographs.iarc.fr/ENG/ Monographs/vol100F/100F22-Index-tables.php.

[4] EPA Method 4435, Method for Toxic Equivalents (TEQS) Determinations for Dioxin-Like Chemical Activity with the CALUX® Bioassay. http://www.xenco.com/content/pdf/tech/ SW846/SW846-4000series/SW846-4435.pdf.

[5] Kukučka P, Audy O, Kohoutek J, Holt E, Kalábová T, Holoubek I, et al. Source identification, spatiotemporal distribution and ecological risk of persistent organic pollutants in sediments from the upper Danube catchment. Chemosphere. 2015;138:777-783. DOI: 10.1016/j.chemosphere.2015.08.001.

[6] Lee WJ, Shih SI, Chang CY, Lai YC, Wang LC, Chang-Chien GP. Thermal treatment of polychlorinated dibenzo-p-dioxins and dibenzofurans from contaminated soils. J Hazard Mater. 2008;160(1):220-227. DOI: 10.1016/j.jhazmat.2008.02.113.

[7] Kasai E, Harjanto S, Terui T, Nakamura T, Waseda Y. Thermal remediation of PCDD/Fs contaminated soil by zone combustion process. Chemosphere. 2000;41(6):857-864. DOI: 10.1016/S0045-6535(99)00535-4.

[8] Reynier N, Blais JF, Mercier G, Besner S. Decontamination of metals, pentachlorophenol, and polychlorined dibenzo-p-dioxins and dibenzofurans polluted soil in alkaline conditions using an amphoteric biosurfactant. Environ Technol. 35(1-4):177-186. DOI: 10.1080/09593330.2013.822005.

[9] Kim Y, Lee D. Solubility enhancement of PCDD/F in the presence of dissolved humic matter. J Hazard Mater. 2002;91(1):113-127. DOI: 10.1016/S0304-3894(01)00364-8.

[10] Kulkarni PS, Crespo JG, Afonso CAM. Dioxins sources and current remediation technologies - A review. Environ Int. 2008;34(1):139-153. DOI: 10.1016/j.envint.2007.07.009.

[11] Jiang JQ. Research progress in the use of ferrate(VI) for the environmental remediation. J Hazard Mater. 2007;146(3):617-623. DOI: 10.1016/j.jhazmat.2007.04.075.

[12] Tiwari D, Lee SM. Ferrate(VI) in the Treatment of Wastewaters: A New Generation Green Chemical. In: Waste Water - Treatment and Reutilization. InTech; 2011. DOI: 10.5772/15500.

[13] Jiang JQ. Advances in the development and application of ferrate(VI) for water and wastewater treatment. J Chem Technol Biotechnol. 2014;89(2):165-177. DOI: 10.1002/jctb.4214.

[14] Tosco T, Petrangeli Papini M, Cruz Viggi C, Sethi R. Nanoscale zerovalent iron particles for groundwater remediation: a review. J Clean Prod. 2014;77:10-21. DOI: 10.1016/j.jclepro.2013.12.026.

[15] Fu F, Dionysiou DD, Liu H. The use of zero-valent iron for groundwater remediation and wastewater treatment: A review. J Hazard Mater. 2014;267:194-205. DOI: 10.1016/j.jhazmat.2013.12.062.

[16] Grittini C, Malcomson M, Fernando Q, Korte N. Rapid dechlorination of polychlorinated biphenyls on the surface of a Pd/Fe bimetallic system. Environ Sci Technol. 1995;29(11):2898-2900. DOI: 10.1021/es00011a029.

[17] Zhou HY, Xu XH, Wang DH. Catalytic dechlorination of chlorobenzene in water by Pd/Fe bimetallic system. J Environ Sci (China). 2003;15(5):647-651. http://www.ncbi.nlm.nih.gov/pubmed/14562926.

[18] Kim JH, Tratnyek PG, Chang YS. Rapid dechlorination of polychlorinated dibenzo-p-dioxins by bimetallic and nanosized zerovalent iron. Environ Sci Technol. 2008;42(11):4106-4112. DOI: 10.1021/es702560k.

[19] Wang Z, Huang W, Peng P, Fennell DE. Rapid transformation of 1,2,3,4-TCDD by Pd/Fe catalysts. Chemosphere. 2010;78(2):147-151. DOI: 10.1016/j.chemosphere.2009.09.066.

[20] Tsitonaki A, Petri B, Crimi M, Mosbæk H, Siegrist Rl, Bjerg Pl. In situ chemical oxidation of contaminated soil and groundwater using persulfate: A review. Crit Rev Environ Sci Technol. 2010;40(1):55-91. DOI: $10.1080 / 10643380802039303$.

[21] Certified Reference Material BCT-529. https://ec.europa.eu/jrc/sites/default/files/rm/BCR-529_cert.pdf. 
[22] Antunes P, Viana P, Vinhas T, Capelo JL, Rivera J, Gaspar EMSM. Optimization of pressurized liquid extraction (PLE) of dioxin-furans and dioxin-like PCBs from environmental samples. Talanta. 2008;75(4):916-925. DOI: 10.1016/j.talanta.2007.12.042.

[23] Hong B, Garabrant D, Hedgeman E, Demond A, Gillespie B, Chen Q, et al. Impact of WHO 2005 revised toxic equivalency factors for dioxins on the TEQs in serum, household dust and soil. Chemosphere. 2009;76(6):727-733. DOI: 10.1016/j.chemosphere.2009.05.034.

[24] ČSN EN 1948-2 (834745) - Technické normy ČSN - Stanovení hmotnostní koncentrace PCDD/PCDF - Část 2: Extrakce a čištění. (Technical standards CSN - Determination of mass concentration of PCDD / PCDF - Part 2: Extraction and purification). http://www.technicke-normy-csn.cz/inc/ nahled_normy.php?norma=834745-csn-en-1948-2\&kat=77746.

[25] ČSN EN 1948-3 (834745) - Technické normy ČSN - Stanovení hmotnostní koncentrace PCDD/PCDF - Část 3: Identifikace a kvantitativní stanovení. (Technical standards CSN - Determination of mass concentration of PCDD / PCDF - Part 3: Identification and quantification). http://www.technicke-normy-csn.cz/inc/ nahled_normy.php?norma=834745-csn-en-1948-3\&kat=77749.

[26] Theron J, Walker JA, Cloete TE. Nanotechnology and water treatment: applications and emerging opportunities. Crit Rev Microbiol. 2008;34(1):43-69. DOI: 10.1080/10408410701710442.

[27] Rickman KA, Mezyk SP. Kinetics and mechanisms of sulfate radical oxidation of $\beta$-lactam antibiotics in water. Chemosphere. 2010;81(3):359-365. DOI: 10.1016/j.chemosphere.2010.07.015.

[28] Wojnárovits L, Takács E. Rate coefficients of hydroxyl radical reactions with pesticide molecules and related compounds: A review. Radiat Phys Chem. 2014;96:120-134. DOI: 10.1016/j.radphyschem.2013.09.003.

[29] Kim JH, Lee JM, Lee HS, Kim JH, Lee JW, Chang YS, et al. Degradation of Polychlorinated Dibenzo-p-Dioxins/Furans Using Heat-Activated Persulfate. Proc Sixth Int Conf Remediation of Chlorinated and Recalcitrant Compounds. Monterey. CA: 2008. http://www.ebs.ieh.ohsu.edu/tratnyek/resources/ docs/KimChangNurmiTratnyek08-PCDDs.pdf. 